\title{
The ICT Used by the English Lecturers for Non-English Study Program Students at IAIN Curup
}

\author{
Eka Apriani $^{1}$ \\ ${ }^{1}$ IAIN Curup \\ 1ekaapriani_90@ymail.com \\ Jumatul Hidayah ${ }^{2}$ \\ ${ }^{2}$ IAIN Curup \\ ${ }^{2}$ hidayah_jumatul@yahoo.com
}

\begin{abstract}
This research is done by the researcher to investigate kinds of ICT used by English lecturers for non-English Study Program students at IAIN Curup and to investigate the roles of ICT for the English lecturer at IAIN Curup. This research used descriptive quantitative Because the questioner's results were evaluated and explained in the explanatory form. The questionnaire used as the instrument to collect the data. Questionnaire about the ICT used by the English lecturers for non-English Study Program students at IAIN Curup and the role of ICT for English Lecturer. Five processes is used to analyze the data from questionnaires in this research. They are (1) data managing of research result, (2) reading/memoing of result, (3) description of result; (4) classifying of research result and (5) interpreting of research result. The result showed that the lecturers always used three types of ICR in teaching English in the classroom, they were the speaker, educational games, and website resources. The reason for them using three types of ICT because it was easy to use and cheap. In using the ICT, the lecturers have a different opinion about About ICT's role in promoting its learning operations. The use of ICT in the teaching and learning system had 7 (seven) roles. It is about the role of ICT in motivating, attracting, and enhancing the success of learners in studying English.
\end{abstract}

ARTICLE HISTORY

Received 12 February 2019 Accepted 30 April 2019

\section{KEYWORDS}

ICT; english lecturers; nonenglish study program

\section{Introduction}

Nowadays, the development of technology almost affects every aspect of life, including the education field. In the other side, increasing the development of technology in the education side have an impact on the actor of this field. Because the growth of technology had affected the students' mindset, thinking or opinion or the way they learn something. That way, they forced to have an innovation to adapt to the progression today. One of the solutions for the teachers or lecturers to adapt to this condition is by using the technology itself. It causes by utilizing the new 
technologies, teachers or lecturers can reach a wider way of teaching media and environment.

In addition, technology can create high-quality learning environments by using more media in teaching and learning processes, according to Nusir et al. (Nusir, Alsmadi, Al-Kabi, \& Sharadgah, 2013). The using of computer, audio, video, and text became a teaching media for the learning process with enormous potential. For instance, the text does not simply allow students to get the teacher"s explanation; yet animated video or catching graphics would give illustration to the materials explained.

In another hand, ICT-based instruction is an effective and efficient method of education and training program. ICT make learning process more flexible and efficient, for example, ICT can improve learning efficiency by connecting learners with learning colleagues from around the globe (Lea, Rogers, \& Postmes, 2002). Technology also helps the teacher in changing traditional approach to classroom activities (students learning centre) and implementing of curriculum more effectively Duhaney, 2016).

In addition, information, communication, and technology (ICT) can improve the quality of university teaching and research. Students can gain much information at once from the many kinds of technology which are used. Interactive media such as images and videos can help learners from text screens and enhance their pedagogical value by stimulating eyes. ICT is not also can improve students' achievement but also students' character. According to Apriani (2006, p1), Positive impact of technology is to construct the personality of a successful student. Good students characters can create good future leadership. Student's should be equipped with the ability of codebreaking, making- meaning, text-using, and text-analyzing with suing good character namely trustworthy, respect, diligence, responsibility, and courage.

ICT is using as the teaching media by the teacher to manage their classroom in teaching and learning process (Apriani, 2017). ICT can be used as the media and method in teaching students especially English Subject. Therefore, the researcher is interested to know the ICT used by the English lecturers for non-English Study Program students at IAIN Curup and the roles of ICT for the English lecturer at IAIN Curup. This research uses descriptive quantitative because the result of questioner will be measured and described in the form of explanation. The instruments used in the study were: Questionnaire about the ICT used by the English lecturers for nonEnglish Study Program students at IAIN Curup and the role of ICT for English Lecturer. In this study, there are five procedures for analyzing questionnaire information. They are (1) information management, (2) memoing / reading, (3) description, (4) classification, and (5) interpretation. 


\section{Literature Review}

\section{Theories of Media Use}

Today, the degree to which individuals adopt new technology varies. It is essential to understand why individuals embrace or dismiss technology as one of the most difficult problems in organizational research. (Davis, Bagozzi, \& Warshaw, 1989). There are four models explaining media use theories. They are model of media wealth, handling of social information, model of dual capacity, and model of adoption of technology. First, Daft and Lengel suggested the media wealth model as a framework to explain how organizational employees make decisions about the use of communication media (Daft \& Lengel, 1986). Another model is the social information-processing model that suggests that the adoption of organizational technologies and communication media can be more explaining by looking at the social environment or situation of the institution or the organization. Fulk, et al. argued that behavior occurs in a social world that is far from neutral in its effects (Fulk, SChmitz, \& Steinfield, 1990). Communicative interaction can affect communication media attitude if media is used as conduct (Miller, 1999). Third, in organizations, Sitkin et al. suggested a dual-capacity media choice model. Any medium of communication conveys two types of messages. The message is made up of information and significance (Sitkin, Sutcliffe, \& Barrios-Choplin, 1992). Fourth, the acceptance model of technology is an adaptation of the reasoned action theory (Davis et al., 1989). Technology plays a part in the model as acceptance and opposition are forms of reasoned action and both are user-friendly.

\section{Approaches to ICT-based education}

Integrating data, communication, and technology (ICT) into the learning process was related to a multitude of techniques and paradigm for learning and teaching. The basics of these paradigms of learning are linked to how they relate to technology in improving the process of teaching and learning..

a. Learning Paradigms

The characteristics of learning paradigm consist of objectivist mode, constructivist mode, cognitive information processing, and socio-cultural mode. First of all, objectivist mode is a mode that is seen as part of an out-there truth. Learning is aimed at uncovering and understanding learning. The traditional technique suits this teaching mode. Second, constructivist mode is a mode that is perceived by learners as creators of their truth. Learning and understanding is a method that learners build through exploration and teaching problem-solving. Third, mode of collaboration is mode of acquiring and learning expertise through group work or interaction. Fourth, the cognitive 
mode of information processing is a mode in which education is a function of the learner's cognitive characteristics. With their learning style, students / trainees can learn the right way. Five, socio-cultural mode is a mode that builds reality for students based on their social environment. Culture and social values is important for students to dictate how they acquire and processes knowledge.

\section{b. Electronic Delivery of Content}

In distance education mode, electronic content delivery is useful because it saves time and costs. Online communication makes it possible for the learners to access the material taxi wherever they are and it can cost less. The adverse part of the ease and velocity of online electronic document delivery is the absence of caution about the amount of transmitted subject matter. An electronic thesis or book chapter can have a capacity of $880 \mathrm{~KB}$ in Adobe Acrobat PDF format and can be over 300 pages. Reading content can be published in different formats on the internet or internet media. Many teachers simply post files for word processing or mobile records (PDF or Postscript) or HTML for viewing with a web browser. Teachers need to bear in mind that learning style and strategies are not the same for all learners. Adult learners tend to be more practical and may not like reading a lot of stuff at once. Young learners may be more visual, such as the incorporation of diagrams, illustrations, and images, and maybe more appropriate for them.

c. Communication Tools

As a communication instrument, ICT can be said. ICT, as the communication instrument, can share experiences of learners in real-time with teachers and partners. In order to solve issues and address case studies, cooperation between learners with teachers or students with online education learners can be structured. This scenario can be used to fix the problem when learning about content established by learners. Online communication can be divided into two primary classifications: synchronous and asynchronous. First of all, synchronous communication is communication in which all learners have to be simultaneously online. It's like calling a telephone. Students can interact simultaneously with their friend. Second, asynchronous is the communication that can occur in any type of interaction at any time and anywhere. It is a non-realtime mode that enables one student to send a message and the other students to $\mathrm{read} /$ listen to / view it whenever and where necessary. The instance is email, fb messanger, Whatsapp messanger, etc.

d. Assessment Tools

ICT as internet educational media requires processes for evaluating and evaluating the job of learners. In traditional assessment, the teacher usually used tests, quizzes, and homework. In online education, teacher also used 
similar approaches but the weakness is the students can get help from another student to answer the questions. Some online education is having physical testing centre but it is not possible to asses one by one student. Some approaches can be used in qualitative evaluation likes opinions, debate, and performance of projects, project-based methods, and peer-review. These approaches can be used in individual or group work.

\section{ICT Types}

ICTs stand for ICTs as a diverse set of technological equipment and resources used to communicate and create, disseminate, store and manage information about something (Tinio:2002, p.4). In other words, Galbraith cited in Molenda (2008: p.11) stated that technology as the systematic program or application of scientific or other that organizing knowledge to practical tasks. In Addition, Heineke (2001) said that technology as a facilitator that can be used to improve quality education. Diem (2011: p.87-90) said that types of ICT is usually use by the teacher are computers, broadcasting technologies (radio and television), telephony, CD ROM, audio or video clips, and Internet. The use of ICT in teaching and learning processes can improve educational performance because this tool makes students motivate and active in the classroom. Internet is also transformational tools which that changing teacher centre learning to students centre learning (Tinio, 2002).

\section{Non-English Study Program at IAIN Curup}

IAIN Curup consists of three (3) faculties; they are Tarbiyah (Education), Dakwah, and Syria. There are nine non Study English Program at IAIN Curup :(1) Islamic Education Study Program, (2) Arabic Education Study Program, (3) Teacher Education for Elementary School Study Program, (4) Islamic Counseling Study Program, (5) Islamic Management Education Study Program, (6) Islamic Broadcasting Communication Study Program, (7) Tafsir Al-Quran Study Program, (8) Religious Courts Study Program, and (9) Islamic Banking Economic Study Program, (10) Islamic Kindegraten Study Program, (11) Islamic Guidance Counseling Study Program, (12) Mathematics Study Program, (13) Indonesia Language Study program, (14) Islamic Economic Study Program. (15) Islamic Constitutional Law Study Program, (16) Islamic Library and Information Science, (17) Islamic Education Study Program (S2), (18) Islamic Management Education Study Program (S2) and (19) Religious Courts Study Program (S2). 


\section{Research Methodology}

\section{Research Design}

There are many kinds of studies that can be adequately used. The researcher used descriptive information in this research, which is presented quantitatively. Descriptive technique is a study that describes any scenario or condition that occurs in the population that is systematic, factual and accurate (Zuriah: 2007, p.47). It means that the situation in field research will be important aspects as the data which will be collected in this research. According to Sugiyono (2009: p.399), the descriptive method is a design used to describe or analyze the results of the study with not focuses on conclusion. It could be argued that Descriptive research aims at describing a phenomenon that has occurred or an event that occurs in the present or actual problems. The researcher describes the data was written from the result of questionnaire. The data from questionnaire was analyzed using quantitative data or percentage analysis.

\section{Subject of The Research}

Merriam in Heigham and Crocker (2005, p.72) started that subject of study is an individual or society that do social action or activity. The subject of the research is the English lecturers for non-English Study Program students at IAIN Curup. Regarding this, the researcher used purposive sampling. In addition, Cresswell (2007, p.165) states that:

\footnotetext{
"In qualitative research, the notion of purposeful sampling is used. This implies that the enquirer chooses people and sites for study because in this research they can intentionally inform knowledge of the research problem and the key phenomenon. It is necessary to make a decision as to who or what should be sampled, how the sampling will take, and how many individuals or sites should be sampled. Furthermore, scientists must decide whether the sampling is compatible with the data required by one of the five approach investigations".
}

\section{Technique For Collecting The Data}

The technique for collecting the data used in this research was the Questionnaire. According to Nasution, questionnaire is a list of question as a technique in collecting the data that will be answered by the respondents themselves (Nasution: 1995, p.65). The questionnaire was given to the English lecturers that teach English for nonEnglish Study Program students at IAIN Curup. 


\section{Instrument of The Research}

A research instrument is an invaluable tool for researchers in collecting the data. So the instrument is measuring tool in the study. The instruments used in the research was: Questionnaire: The researcher gave to the respondent the questionnaire about the ICT used by the English lecturers for non English Study Program students at IAIN Curup and the role of using Information, Communication, and Technology (ICT) for English Lecturer.

\section{Techniques For Analyzing The Data}

To analyze the data from the questionnaire, the researcher analyzed by using these steps: they are (1) data managing, (2) reading/ memoing, (3) description; (4) classifying and (5) interpreting. This process following (Sudjana: 2004, p.43):

1. Verification of data is to check of trust and complete the questionnaire that was answered by English lecturer.

2. Data arranged by using a table;

3. Data analyzed by using percentage formula:

$$
\begin{aligned}
& \qquad \mathrm{P}=\frac{\mathrm{F}}{\mathrm{N}} \times 100 \% \\
& \mathrm{P}=\text { Percentage of result } \\
& \mathrm{F}=\text { Total frequency for each item } \\
& \mathrm{N}=\text { Number of lecturer/ students }
\end{aligned}
$$

4. Data from questionnaire analyzed based on the research questions.

5. The result data was described one by one.

6. Write conclusions about the result.

\section{Discussion}

The result of this study was the researcher already gave the ICT questionnaire to all English lecturer that taught English subject in Non-English Study Program. There were nine non-English study program at IAIN Curup that given questionnaire by the researcher; Islamic Education Study Program, Arabic Education Study Program, Teacher Education for Elementary School Study Program, Islamic Counseling Study Program, Islamic Management Education Study Program, Islamic Broadcasting Communication Study Program, Tafsir Al-Quran Study Program, Religious Courts Study Program, and Islamic Banking Economic Study Program. All of the English lecturers finished filling the questionnaire. There was 7 (seven) English Lecturer that 
taught English I and II in non- English Study Program. There were two men and five women. The researcher took three days to give the questionnaire to an English lecturer.

\section{Types of ICT}

The following table showed the result of the types of ICT that is used by seven lecturers in English study program when they are teaching in the classroom:

Table 1. Examples of ICT

\begin{tabular}{|c|c|c|c|c|c|c|c|c|c|}
\hline No & $\begin{array}{l}\text { English Lecturers } \\
\text { Types of ICT }\end{array}$ & $\begin{array}{l}\text { EL } \\
\text { I }\end{array}$ & $\begin{array}{l}\text { EL } \\
\text { II }\end{array}$ & $\begin{array}{l}\text { EL } \\
\text { III }\end{array}$ & $\begin{array}{l}\text { EL } \\
\text { IV }\end{array}$ & $\begin{array}{l}\mathrm{EL} \\
\mathrm{V}\end{array}$ & $\begin{array}{l}\text { EL } \\
\text { VI }\end{array}$ & $\begin{array}{l}\text { EL } \\
\text { VII }\end{array}$ & Total \\
\hline 1 & Computer & $\sqrt{ }$ & $\sqrt{ }$ & $\sqrt{ }$ & $\sqrt{ }$ & - & $\sqrt{ }$ & $\sqrt{ }$ & 6 \\
\hline 2 & LCD & $\sqrt{ }$ & $\sqrt{ }$ & $\sqrt{ }$ & $\sqrt{ }$ & - & $\sqrt{ }$ & $\sqrt{ }$ & 6 \\
\hline 3 & Television & $\sqrt{ }$ & - & - & - & - & - & - & 1 \\
\hline 4 & Speaker & $\sqrt{ }$ & $\sqrt{ }$ & $\sqrt{ }$ & $\sqrt{ }$ & $\sqrt{ }$ & $\sqrt{ }$ & $\sqrt{ }$ & 7 \\
\hline 5 & Radio & - & - & $\sqrt{ }$ & - & - & - & - & 1 \\
\hline 6 & $\mathrm{~B} \log$ & $\sqrt{ }$ & - & - & $\sqrt{ }$ & - & $\sqrt{ }$ & $\sqrt{ }$ & 4 \\
\hline 7 & Email & $\sqrt{ }$ & $\sqrt{ }$ & $\sqrt{ }$ & - & $\sqrt{ }$ & - & $\sqrt{ }$ & 5 \\
\hline 8 & Youtube & $\sqrt{ }$ & - & $\sqrt{ }$ & $\sqrt{ }$ & - & $\sqrt{ }$ & $\sqrt{ }$ & 5 \\
\hline 9 & Internet Connection & $\sqrt{ }$ & $\sqrt{ }$ & $\sqrt{ }$ & $\sqrt{ }$ & - & $\sqrt{ }$ & $\sqrt{ }$ & 6 \\
\hline 10 & Video & $\sqrt{ }$ & - & $\sqrt{ }$ & $\sqrt{ }$ & $\sqrt{ }$ & $\sqrt{ }$ & $\sqrt{ }$ & 6 \\
\hline 11 & Telephone & - & - & $\sqrt{ }$ & $\sqrt{ }$ & - & - & $\sqrt{ }$ & 3 \\
\hline 12 & Online databases & $\sqrt{ }$ & $\sqrt{ }$ & $\sqrt{ }$ & - & - & - & - & 3 \\
\hline 13 & Online library & - & - & $\sqrt{ }$ & $\sqrt{1}$ & - & - & - & 2 \\
\hline 14 & Audio graphics & $\sqrt{ }$ & $\sqrt{ }$ & $\sqrt{ }$ & - & - & - & - & 3 \\
\hline 15 & Audio conferencing & $\sqrt{ }$ & - & - & - & - & - & - & 1 \\
\hline 16 & $\begin{array}{l}\text { Computer } \\
\text { conferencing }\end{array}$ & $\sqrt{1}$ & - & - & - & - & - & $\sqrt{ }$ & 2 \\
\hline 17 & $\begin{array}{l}\text { Broadcast radio and } \\
\text { television }\end{array}$ & $\sqrt{ }$ & - & - & - & - & - & - & 1 \\
\hline 18 & Teleconferencing & $\sqrt{ }$ & - & - & - & - & - & - & 1 \\
\hline 19 & $\begin{array}{l}\text { Audio and video } \\
\text { tapes CDs }\end{array}$ & $\sqrt{ }$ & - & $\sqrt{ }$ & $\sqrt{ }$ & $\sqrt{ }$ & - & - & 4 \\
\hline 20 & $\begin{array}{l}\text { Computer files } \\
\text { transfer }\end{array}$ & $\sqrt{ }$ & - & $\sqrt{ }$ & $\sqrt{ }$ & $\sqrt{ }$ & $\sqrt{ }$ & - & 5 \\
\hline 21 & Virtual conferences & $\sqrt{ }$ & - & - & - & - & - & - & 1 \\
\hline 22 & Recorded audio & $\sqrt{ }$ & $\sqrt{ }$ & $\sqrt{ }$ & $\sqrt{ }$ & $\sqrt{ }$ & - & - & 5 \\
\hline
\end{tabular}




\begin{tabular}{llllllllll}
\hline 23 & Social media & $\sqrt{ }$ & $\sqrt{ }$ & $\sqrt{ }$ & $\sqrt{ }$ & $\sqrt{ }$ & - & - & 5 \\
\hline 24 & e-learning & - & - & $\sqrt{ }$ & - & $\sqrt{ }$ & - & - & 2 \\
\hline 25 & e-book & $\sqrt{ }$ & $\sqrt{ }$ & $\sqrt{ }$ & $\sqrt{ }$ & $\sqrt{ }$ & - & - & 5 \\
\hline 26 & Online forum & - & $\sqrt{ }$ & $\sqrt{ }$ & - & $\sqrt{ }$ & - & $\sqrt{ }$ & 4 \\
\hline 27 & $\begin{array}{l}\text { Interactive } \\
\text { whiteboard }\end{array}$ & - & - & - & - & - & - & - & 0 \\
\hline 28 & Educational games & $\sqrt{ }$ & $\sqrt{ }$ & $\sqrt{ }$ & $\sqrt{ }$ & $\sqrt{ }$ & $\sqrt{ }$ & $\sqrt{ }$ & 7 \\
\hline 29 & Online journal & $\sqrt{ }$ & $\sqrt{ }$ & $\sqrt{ }$ & $\sqrt{ }$ & $\sqrt{ }$ & - & - & 5 \\
\hline 30 & Website resources & $\sqrt{ }$ & $\sqrt{ }$ & $\sqrt{ }$ & $\sqrt{ }$ & $\sqrt{ }$ & $\sqrt{ }$ & $\sqrt{ }$ & 7 \\
\hline
\end{tabular}

Based on the table above, English lecturers in English study program have different in using ICT when they are teaching. English lecturer, I used 23 types of ICT when teaching. He used computer, LCD, television, speaker, blog, email, youtube, internet connection, video, online databases, audio graphics, computer conferencing, broadcast radio and television, teleconferencing, audio and videotapes CDs, computer files transfers, virtual conferences, recorded sound, social media, e-book, online forum, online journal, website resources. English lecturer II only used 14 types of ICT such as a computer, LCD, speaker, internet connection, online databases, recorded audio, social media, e-book, online forum, educational games, online journal, website resources. Then English lecturer III used 21 types of ICT. He used a computer, LCD, speaker, radio, email, youtube, internet connection, video, telephone, online databases, online library, audio and videotapes CDs, computer files transfers, recorded audio, social media, e-learning, e-book, interactive whiteboard, educational games, online journal, website resources. English lecturer IV only used 17 types of ICT such as a computer, LCD, speaker, blog, youtube, internet connection, video, telephone, online library, audio and videotapes CDs, computer files transfers, recorded audio, social media, e-book, educational games, online journal, website resources.

Furthermore, English lecturer V used just 13 types of ICT in teaching in the classroom. Such as speaker, email, internet connection, audio and videotapes CDs, computer files transfers, recorded sound, social media, e-learning, e-book, interactive whiteboard, educational games, online journal, website resources. English lecturer VI only used ten types of ICT such as a computer, LCD, speaker, blog, email, internet connection, video, computer files transfers, educational games, website resources. And the last lecturer used 13 types of ICT. Such as a computer, LCD, speaker, blog, email, youtube, internet connection, video, telephone, computer conferencing, online forum, educational games, website resources.

Although there are many types of ICT, not all the lecturers used all the ICT. Only 3 of 30 ICT that the lecturer used in teaching English in the classroom such as a speaker, educational games, and website resources. They used the three types of ICT 
because it is easy to use and cheap. But there are only one types of ICT that never used in teaching by the lecturers, which is an interactive whiteboard.

\section{The Role of Using ICT in Teaching and Learning Process}

Based on the findings, there are seven roles of using ICT in teaching and learning process. First, Using ICT makes students concentrate more on their learning if they used ICT in the learning process. The students are interesting when teaching using ICT in teaching process. The students more concentrate to listen the instruction and do the task. Second, Using ICT makes the students would try harder in what they are learning when they used ICT. The students should be active and creative in learning process. They learned material invidually and grouply. They must solve the problem when they found the difficulties in understanding the material. Third, Using ICT students feel more autonomous in their learning like they can repeat exercises if needed, explore in more detail topics that they are interested in, etc. The students can learn material independently in their home. Fourth, Using ICT makes students understand more easily what they have learned. ICT makes material more easy to understanding by students. ICT makes material clearly. Fifth, Using ICT students remember more easily what they have discovered when using ICT in the learning process. the students are more interested in the teaching and learning process when they used ICT. ICT can improve the class climate like students more engaged and less disturbing when they are learning. Sixth, the using of ICT in the teaching and learning process have positive impacts on students' achievement. Seventh, ICT facilities collaborative work between students in the learning process.

\section{Conclusions}

Even there are so many types of ICT; the lecturers always used three types of them in teaching English in the classroom such as the speaker, educational games, and website resources. This ICT used for teaching English Skill for students' in non English Study Program. They used the three types of ICT because it is easy to use and cheap. In using the ICT, the lecturers have a different opinion about the role of it in supporting their teaching activities. It concerns the role of ICT motivate, attract, and increase the students' achievement in learning English. ICT can motivate them in the teaching and learning process because the material being interesting. Because the material is interesting, so make the students' achievement is improving. 


\section{References}

Daft, R. L., \& Lengel, R. H. (1986). Organizational Information Requirements, Media Richness and Structural Design. Management Science, 32. https://doi.org/10.2307/2631846

Davis, F., Bagozzi, R., \& Warshaw, P. (1989). User Acceptance of Computer Technology: A Comparison of Two Theoretical Models. Management Science, 35, 982-1003. https://doi.org/10.1287/mnsc.35.8.982

Duhaney, D. C. (2002). Technology and the educational process: Transforming classroom activities. Int'l $J$ of Instructional Media, 27(1), 67-72. Retrieved from

http://pedagogy21.pbworks.com/f/Technology+and+the+Educational+Proces s.pdf accessed on $15^{\text {th }}$ april, 2016.

Fulk, J., SChmitz, J., \& Steinfield, C. (1990). A Social Influence Model of Technology use. In Organizations and Communication Technology (pp. 117140). https://doi.org/10.4135/9781483325385.n6

Lea, M., Rogers, P., \& Postmes, T. (2002). SIDE-VIEW: Evaluation of a system to develop team players and improve productivity in Internet collaborative learning groups. British Journal of Educational Technology, 33(1), 53-63. https://doi.org/10.1111/1467-8535.00238

Miller, K. (1999). Organizational communication: approaches and processes. Belmont, California: Wadsworth Cengage Learning.

Nusir, S., Alsmadi, I., Al-Kabi, M., \& Sharadgah, F. (2013). Studying the Impact of Using Multimedia Interactive Programs on Children's Ability to Learn Basic Math Skills. E-Learning and Digital Media, 10(3), 305-319. https://doi.org/10.2304/elea.2013.10.3.305

Sitkin, S. B., Sutcliffe, K. M., \& Barrios-Choplin, J. R. (1992). A Dual-Capacity Model of Communication Media Choice in Organizations. Human Communication Research, 18(4), 563-598. https://doi.org/10.1111/j.14682958.1992.tb00572.x

Zuriah, Nurul. (2007). Metodologi Penelitian Sosial dan Pendidikan: Teori Aplikasi. Bumi Aksara, Jakarta.

Sujana. (2004). Pengantar statistic pendidikan. Jakarta: Raja Grafindo Persada.

Sugiyono. 2009. Metode Penelitian Pendidikan. Bandung: Alfabeta.

Heigham, Juanita and Robert A. Crocker. (2005). Qualitative Research in Applied Linguistic: A practia; Introduction. New York: Palgrave Macmillan. 
Creswell, John W. (2007). Qualitative Inquiry and Research Design Choosing Among Five Approach $2^{\text {nd }}$. Sage Publication:California.

Nasution, Irwan. (1995). Metode Penelitian Sosial. Jakarta: Rineka Cipta

Apriani, E. (2016). A New Literacy: The Role of Technology to Develop Student's Character. Ta'dib: Journal of Islamic Education (Jurnal Pendidikan $\begin{array}{lllll}\text { Islam }), 21(1), & 59 & - & 72 . & \text { Retrieved }\end{array}$ http://jurnal.radenfatah.ac.id/index.php/tadib/article/view/742

Apriani, E. (2017). Utilizing Preservice English Teachers Strategies and Classroom Management at Junior High School in Rejang Lebong Regency. ENGLISH FRANCA: Academic Journal of English Language and Education, 1(2), 149194. 